\title{
Archiwalia ZWiązane Z Kniaziami Trubeckimi W ZESPOLE ArChiwum WarSZaWskie RadziwiŁŁów - POCHODZENIE I PODZIAE TYPOLOGICZNY
}

http://dx.doi.org/10.12775/AKZ.2015.002

Słowa kluczowe

Trubeccy; archiwum Radziwiłłów; Radziwiłłowie; archiwa rodowe; Archiwum Główne Akt Dawnych;

Keywords

the Trubecki family; the Radziwiłł family; the Radziwiłł family archives; family archives; the Central Archives of Historical Records

Streszczenie

Prezentowany artykuł ma na celu przybliżenie przechowywanych w zespole Archiwum Warszawskie Radziwiłłów materiałów związanych z dziejami rodu kniaziów Trubeckich. Można podzielić je na dwie grupy. Pierwsza zawiera informacje o trzech kolejnych przedstawicielach tej rodziny osiadłych w XVII w. na terenie Rzeczypospolitej (Jurij Nikiticz, Piotr Wigant i Jerzy Trubecki) i jest wynikiem ich działalności aktotwórczej. Druga część przechowywanych w Archiwum Głównym Akt Dawnych dokumentów związanych z dziejami tej rodziny, została zgromadzona w związku z problemem wypłaty „sum trubeckich” stanowiących odszkodowanie za przekazanie przez 
Rzeczpospolitą Trubecka Moskwie. Starania o jej uregulowanie podejmowała wdowa po Piotrze Wigancie Trubeckim, Halszka Drucka- Sokolińska wraz z drugim mężem Krzysztofem Wołodkowiczem, a po jej śmierci sam Wołodkowicz, który w wyniku wyjazdu pasierba Jerzego Trubeckiego do Moskwy w 1657 r. stał się spadkobiercą zasądzonej kwoty.

W artykule podjęta została próba ustalenia drogi, którą wspomniane dokumenty znalazły się w Archiwum Głównym Akt Dawnych. Pozwoliło to wysunąć hipotezę, że twórcą wspomnianego zbioru dokumentów był wojewoda miński Krzysztof Wołodkowicz, a ich przejście do Archiwum Radziwiłłów nastąpiło w wyniku koligacji rodzinnych. Spadkobiercą Wołodkowicza był Aleksander Hilary Połubiński, a następnie wraz z ręką jego córki Anny Marianny dokumenty te znalazły się w rękach Radziwiłłów z młodszej kleckiej linii rodu. Dokonano także próby systematyzacji omawianych archiwaliów według podziału na akta prywatne, akta prawno-majątkowe, akta administracyjno-gospodarcze, akta związane z działalnością publiczną i varia.

D) zieje kniaziowskiego rodu Trubeckich w polskiej historiografii nie dotej rodziny przedstawił, jeszcze w XIX w., Józef Wolff w swej pracy o kniaziowskich rodach pochodzenia litewskiego i ruskiego ${ }^{1}$. Losy Trubeckich trwale wpisują się w burzliwe dzieje pogranicza Wielkiego Księstwa Litewskiego i Państwa Moskiewskiego. Po okresie panowania Jagiellonów ich rodowa siedziba Trubeck ${ }^{2}$ w początkach XVI w. znalazła się w rękach moskiewskich carów. Wraz z nią zwierzchność Moskwy uznali i sami Trubeccy³. Zmianę sytuacji przyniósł dopiero okres Wielkiej Smuty, gdy doszło do rozłamu w obrębie rodziny. Z dwóch synów Nikity Trubeckiego - Aleksiej pozostał wierny caratowi, a Jurij związał się z Rzeczpospolitą, dając w ten sposób początek

${ }^{1}$ J. Wolff, Kniaziowie litewsko-ruscy od końca czternastego wieku, Warszawa 1895, s. $541-546$.

2 Trubeck lub w jęz. rosyjskim Трубчевск to dziś niewielkie miasteczko położone na terenie obwodu briańskiego. Na dzień 1 stycznia 2015 r. populacja Trubczewska wynosiła dokładnie 13921 mieszkańców. Informacja na podstawie raportu rosyjskiej Federalnej Służby Państwowej Statystyki „Численность Населения Российской Федерации по муниципальным образованиям на 1 января 2015 года", Москва 2015. Raport do ściągnięcia ze strony: http://www.gks.ru/free_doc/doc_2015/bul_dr/ mun_obr2015.rar (dostęp z dnia 11 listopada 2015 r.), tablica nr 29-15.

${ }^{3}$ Oficjalnie nastąpiło to po zawarciu pokoju w 1503 r., ale Trubeccy przysięgę wierności carowi złożyli już w 1500 r. - K. Pietkiewicz, Wielkie Księstwo Litewskie pod rzadami Aleksandra Jagiellończyka, Poznań 1995, s. 105. 
siedemnastowiecznej polsko-litewskiej linii tego rodu. Jej istnienie nie było długie: skończyło się już w 1657 r., gdy ostatni przedstawiciel rodu, syn Piotra Wiganta i wnuk wspomnianego Jurija Nikiticza, Jerzy Wigant Trubecki, został zmuszony do wyjazdu do Moskwy ${ }^{4}$.

W Archiwum Warszawskim Radziwiłłów (AGAD) zachowała się część archiwaliów przybliżająca dzieje tej linii rodu Trubeckich. Znajdują się one w dziale X tego zespołu - „Papiery domów obcych”, w serii „Papiery Połubińskich i rodzin z nimi spokrewnionych z lat 1513-1686” stanowiącej część dawnego archiwum tej rodziny. Łącznie są to 22 jednostki archiwalne (sygn. 173-188, 192-197). Już pobieżna analiza zawartości tych źródeł pozwala stwierdzić, że można je podzielić na dwie części: jedna związana jest z dziejami rodziny Trubeckich (szczególnie z Piotrem Wigantem), druga to dokumenty związane z problemem wypłaty „sum trubeckich”, czyli przyznanej rekompensaty za Trubeck przekazany Rosji. Grupa archiwaliów z tej drugiej części powstała już po 1657 r., czyli dacie wyjazdu ostatniego przedstawiciela tej rodziny w Rzeczypospolitej Jerzego Trubeckiego do Moskwy, co oznacza, że formalnie nie są już one wynikiem działalności aktotwórczej tej rodziny. W wypadku omawianych materiałów można więc mówić o zbiorze archiwalnym.

\section{Geneza ZBIORU DOKUMENTów}

Chcąc odpowiedzieć na pytanie o pochodzenie i przyczynę zgromadzenia materiałów archiwalnych związanych z Trubeckimi, przechowywanych w Archiwum Warszawskim Radziwiłłów, należy na początku zwrócić uwagę na niejasną kwestię archiwum tej rodziny. Nasuwa się tu od razu kilka pytań. Ród ten panował w Trubecku przez wiele pokoleń, stąd pytanie: czy $\mathrm{w}$ tym czasie powstało jakieś archiwum rodzinne? $\mathrm{Z}$ jednej strony wydaje się to prawdopodobne, $\mathrm{z}$ drugiej jednak strony fakt, że dobra te pozostawały w obrębie jednej rodziny przez cały XV i XVI w., mógł spowodować, że ilość materiałów archiwalnych nie musiała być duża. W tym okresie dokumentacja gospodarcza nie miała jeszcze charakteru masowego, jak to było w kolejnych stuleciach, a podziały jedynie wewnątrz rodziny (brak śladów

${ }^{4}$ Wspomniany Jerzy po wyjeździe został uznany za spadkobiercę bezpotomnego Aleksieja Trubeckiego. Z małżeństwa z Iryną Golicyną miał on dwóch synów Iwana i Jurija - П. Долгоруков, Российская родословная книга, ч. 1, Санкт Петербургъ 1854 , s. 321. 
po zastawach majątku z tego okresu) nie stwarzały potrzeby prowadzenia aż tak ścisłej inwentaryzacji ${ }^{5}$. Włość trubecka była podzielona później na kilka części zgodnie z rozrostem rodziny. Zakładając hipotetycznie istnienie archiwum, czy za tymi podziałami włości szły także podziały archiwaliów, czy może pozostawiono jedno centralne, rodowe archiwum? Ta druga opcja jest także prawdopodobna, gdyż mimo podziałów w obrębie rodziny chyba wszystkie linie posiadały też jakąś część samego Trubecka. Jakie były późniejsze losy archiwaliów i co się z nimi stało? Czy Jurij Nikiticz, wyjeżdżając do Wielkiego Księstwa Litewskiego, zabrał ze sobą jakieś dokumenty? Jaka ich część pozostała w Rosji? Niestety bez gruntownych kwerend przede wszystkim w archiwach naszych wschodnich sąsiadów (głównie Rosja, Białoruś, Ukraina, a uzupełniająco na pewno także Litwa) pytanie to musi pozostać bez odpowiedzi.

Można jednak pokusić się o próbę odpowiedzi na pytanie, jak mogły wyglądać losy dokumentacji wytworzonej już po powrocie Trubeckich do Rzeczypospolitej. Wiadomo, że prawdopodobnie nie była ona zbyt obszerna, chociażby ze względu na krótki okres, w którym była wytwarzana. Od przyjazdu Jurija Nikiticza do Rzeczypospolitej do przekazania Trubecka z powrotem Rosji upłynęło maksymalnie około 35 lat, a formalnie otrzymał on przecież Trubeck dopiero w $1621 \mathrm{r}^{6}$, czyli ćwierć wieku przed jego utratą.

Już analiza zachowanych w Archiwum Warszawskim Radziwiłłów dokumentów pozwala na wysunięcie pewnych wniosków co do losów wytworzonych wtedy archiwaliów. Nie można wykluczyć, że około 1643 r. archiwum trubeckie mogło ulec podziałowi. Nastąpić to mogło najprawdopodobniej w wyniku puszczenia w arendę dóbr Trubeck. Piotr Wigant Trubecki wraz z żoną Halszką z Druckich-Sokolińskich, przenosząc się do Połujkowicz, zgodnie z ustaleniami umowy z Pawłem Sołtykiem zabrali zapewne część dokumentacji ze sobą, przynajmniej tej najcenniejszej, np. przywileje królewskie. Teza o podziale jest tym bardziej prawdopodobna, że w rękach Piotra Wiganta pozostawała też nadal jakaś część włości trubeckiej skupiona wokół Horodca $^{7}$. Z kolei dokumentacja gospodarcza pozostałej części włości, taka

5 Za zwrócenie uwagi na taką możliwość bardzo dziękuję dr. hab. Wiesławowi Nowosadowi z Instytutu Historii i Archiwistyki UMK w Toruniu.

6 Stało się to na mocy przywileju Zygmunta III Wazy - J. Wolff, dz. cyt., s. 544.

7 Archiwum Główne Akt Dawnych (dalej AGAD), Archiwum Warszawskie Radziwiłłów (dalej AR), dz. X, sygn. 177, s. 24-27. 
jak inwentarze powinności poddanych itp., mogła nadal pozostać w Trubecku. Takie rozwiązanie sugeruje także fakt, że zarządca zamku za czasów Trubeckich Eodim Poręba po przejęciu dóbr przez Sołtyka pozostał nadal na swym stanowisku, zresztą aż do utraty Trubecka na rzecz Moskwy. Wskazuje na to protestacja, jaką Sołtyk złożył w sądzie grodzkim starodubowskim 5 IV 1647 r. Oskarżał on w niej wspomnianego Porębę, który - jak wyraźnie podkreślił - zarządzał zamkiem trubeckim zarówno za czasów Piotra Trubeckiego, jak i jego, o wyrządzenie szkód, w tym kradzież. Sołtyk zgłaszał, że Poręba niedawno uciekł i spowodował straty w wysokości 50 tys. zł polskich. Wśród ukradzionych przez niego rzeczy były m.in. puste membrany, co sugeruje, że przedmiotem kradzieży mogły być także jakieś dokumenty. Sołtyk przypuszczał, że Poręba uciekł w stronę granicy moskiewskiej, więc prosił, aby ścigać go jako zdrajcę ${ }^{8}$.

Wpływ na wytworzoną przez Trubeckich dokumentację mogło mieć też przekazanie Trubecka w ręce Moskwy. Sołtyk zapewne część akt zabrał ze sobą, opuszczając miasto. Było to tym bardziej konieczne, że dobra te zostały odebrane mu wcześniej, niż to wynikało z umowy dzierżawy. Musiał więc mieć jakąś podstawę, na której mógł udowadniać swe roszczenia. Dokumentów z tego okresu dotyczących Trubeckich należałoby więc poszukiwać także $\mathrm{w}$ archiwach tej rodziny.

Nie jest znany wpływ wyjazdu nieletniego jeszcze Jerzego Trubeckiego do Moskwy na zasób rodzinnego archiwum. Czy zabrał on ze sobą część otrzymanych po ojcu dokumentów, np. wystawionych przez carów, jeżeli takie były, czy może pozostawił całość posiadanego archiwum swemu opiekunowi Krzysztofowi Wołodkowiczowi, aby pomóc mu ubiegać się o zwrot „sum trubeckich"? Każda z tych opcji jest możliwa. Za zabraniem przez niego dokumentów może przemwiać np. brak przywileju z 1621 r., na mocy którego jego dziadek Jurij Nikiticz otrzymał część Trubecka. Powinien on być przecież przejęty po śmierci ojca przez Piotra Wiganta Trubeckiego. Z drugiej strony, z dokumentów wystawianych przez Jerzego Trubeckiego w związku z wyjazdem widać, że liczył on w przyszłości na powrót w rodzinne strony ${ }^{9}$.

Bezpośrednim powodem zgromadzenia materiałów znajdujących się dziś w Archiwum Warszawskim Radziwiłłów były starania o uzyskanie odszkodowania za Trubeck, obiecanego przez króla i sejm. Widać to chociażby po

8 Tamże, sygn. 188 , s. 26-27.

9 Tamże, sygn. 196, s. 11-12. 
rodzaju archiwaliów, których zdecydowaną większość stanowią właśnie kwity dłużne, jak i dokumentacja procesowa związana z problemem uregulowania niespłaconych długów Piotra Wiganta. Były one potrzebne do udokumentowania roszczeń finansowych. O związku wspomnianego zbioru archiwaliów ze sprawą „sum trubeckich” świadczy też chociażby całkowity brak informacji o sporze sądowym prowadzonym przez Piotra Wiganta i Halszkę Trubeckich z Adamem Kryckim o dobra Horodyszcze, zakończonym ich bezprawnym zajęciem i skazaniem Halszki na banicję ${ }^{10}$. Spór ten był więc bardzo znaczący i miał daleko idące konsekwencje, niemniej w przechowywanych w Archiwum Głównym Akt Dawnych archiwaliach nie ma o nim żadnych informacji, gdyż nie miał wpływu na wielkość rekompensaty za utracony Trubeck ${ }^{11}$.

Znajdująca się w Archiwum Warszawskim Radziwiłłów dokumentacja związana z kniaziami Trubeckimi i wypłatą „sum trubeckich” powstała na bazie archiwaliów zgromadzonych i systematycznie uzupełnianych przez wojewodę mińskiego Krzysztofa Wołodkowicza, który w wyniku spraw losowych (śmierć żony Halszki Druckiej-Sokolińskiej, wyjazd Jerzego Trubeckiego do Moskwy) stał się jedynym spadkobiercą dóbr po Trubeckich, w tym wspomnianych „sum trubeckich”. Archiwalia te były także uzupełniane już po wyjeździe Jerzego Trubeckiego, czego świadectwem są chociażby materiały z procesu przed sądem walnym w 1659 r. $^{12}$, czy cały szereg rachunków kasowych z lat 60 . XVII w. ${ }^{13}$

W tym miejscu należałoby wspomnieć o dwóch interesujących dokumentach przybliżających losy prezentowanych archiwaliów. Jeden z nich to sumariusz dokumentów dotyczących Trubecka i będących w posiadaniu Krzysztofa Wołodkowicza, sporządzony osobiście przez niego 7 III 1659 r. ${ }^{14} \mathrm{~W}$ jego świetle przechowywane przez wojewodę nowogródzkiego dokumenty dotyczące spraw trubeckich podzielone były na 15 fascykułów. Powstał on zapewne podczas przygotowań do procesu z Bazylim Sołtykiem, do którego miało

10 J. Wolff, dz. cyt., s. 544.

11 W zachowanych archiwaliach znajdują się co prawda dwa dokumenty dotyczące sporu Piotra Wiganta z Adamem z Byszowca Kryckim, ale chyba chodzi tu o jakiś inny konflikt, gdyż nie ma w nich odniesienia do dóbr Horodyszcze, a wspomniany jest tylko spór graniczny o dwa uroczyska („pustosze”) i dwa jeziora - AGAD, AR, dz. X, sygn. 179, s. 7-8.

12 Tamże, sygn. 194, s. 31-50.

13 Tamże, s. 51-57.

14 Tamże, sygn. 197, s. 1-7. 
dojść miesiąc później, w czasie sejmu walnego. Być może sporządzenie sumariusza miało na celu określenie stanu posiadania dowodów prawnych w zbliżającym się procesie i ewentualnego ich wzbogacenia np. o wypisy z ksiąg sądowych. Rzeczywiście porównanie z zawartością obecnie znajdujących się w Warszawie archiwaliów pozwala zauważyć, że od tego czasu zbiór ten został uzupełniony. Znalazły się w nim np. dokumenty dotyczące uregulowania długów z Samuelem Kułakiem ${ }^{15}$ czy długiej serii procesów z Samuelem Porażyckim ${ }^{16}$, a których w owym sumariuszu nie wspomniano. Odnotowana jest także odwrotna sytuacja: w sumariuszu wzmiankowane są np. materiały dotyczące sporu o klejnoty Halszki Druckiej-Sokolińskiej, w tym cztery dekrety trybunalskie ${ }^{17}$. Były one wspomniane w czasie procesu z 1659 r., ale nie ma ich obecnie w zasobie Archiwum Warszawskiego Radziwiłłów. Być może doszło do uregulowania tej sprawy z Bazylim Sołtykiem jako spadkobiercą Pawła i dokumenty te zostały mu zwrócone.

Drugi dokument podający nieznane informacje o losach archiwaliów Trubeckich to relacja Wołodkowicza z 14 I 1661 r. zgłoszona w sądzie grodzkim nowogródzkim. Informował on, że zaginęła mu szkatuła z dokumentami dotyczącymi Trubecka. Nastąpiło to w czasie najazdu wojsk Chowańskiego, gdy pospiesznie ewakuował się ze swoich dóbr Łyskowo w powiecie wołkowyskim. Przyznawał on szczerze, że nie wie, jak do tego doszło, „czyli tej szkatuły wziąć zabaczono, czyli też jako przygodnie zginęła abo przez kogo wzięta była" ${ }^{\prime 18}$. Najazd kniazia Iwana Chowańskiego nastąpił na przełomie 1659 i 1660 r., więc w chwili protestacji upłynął już zapewne rok od zaginięcia dokumentów. Wśród utraconych wtedy akt wspomniane były m.in. dekret sejmowy o podziale „sum trubeckich” z 1659 r., wzajemna „likwidacja” przeprowadzona z Bazylim Sołtykiem, potwierdzenie królewskie praw do majątku po Jerzym Trubeckim i list w tej sprawie podskarbiego litewskiego Wincentego Korwina Gosiewskiego z poleceniem intromisji w otrzymane dobra ${ }^{19}$. W przechowywanych w Archiwum Warszawskim Radziwiłłów materiałach znajdują się wspomniane dokumenty, a ich cechy zewnętrzne (np. pieczęcie i podpisy) wskazują że nie są to odpisy lub kopie, tylko oryginały. Znaczyłoby to, że zaginiona szkatuła w końcu się odnalazła.

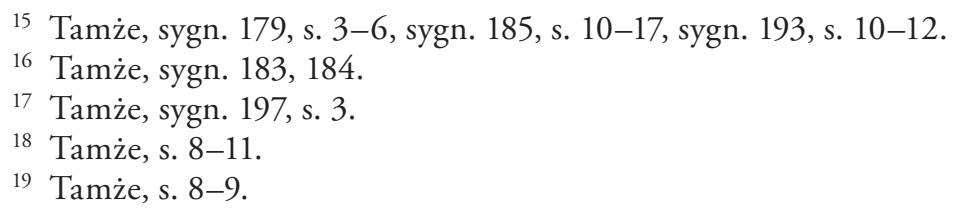


Możliwa jest także prawdopodobna rekonstrukcja drogi, jaką przebyły te archiwalia, nim zostały włączone do zasobu Archiwum Głównego Akt Dawnych. Wpłynęły na to koligacje rodzinne i związane z tym dziedziczenie. Wyjeżdżając do Moskwy, Jerzy Trubecki swoim spadkobiercą uczynił swego ojczyma Wołodkowicza (matka Jerzego Halszka Drucka-Sokolińska już nie żyła). Po Wołodkowiczu jego następcą został z kolei Aleksander Hilary Połubiński ożeniony z córką wojewody mińskiego Zofią Konstancją ${ }^{20}$. To Połubiński już po śmierci Wołodkowicza był odbiorcą reszty „sum trubeckich”. Jemu też został wystawiony najmłodszy dokument w zbiorze: rachunek z 15 IV 1670 r. zawierający zestawienie wypłat rat za lata $1664-1670^{21}$.

Aleksander Hilary Połubiński miał dwóch synów - Dominika Jana i Krzysztofa Konstantego. Obaj zmarli bezpotomnie, Dominik Jan w 1683 r. na Węgrzech w czasie wyprawy wiedeńskiej, a Krzysztof Konstanty w sierpniu 1685 r. ${ }^{22}$ Spowodowało to wybuch sporów o schedę po tej linii Połubińskich. Zaostrzeniu sytuacji sprzyjał też zapis z testamentu Aleksandra Hilarego Połubińskiego, w którym odsuwał od dziedziczenia boczne linie rodziny na rzecz bezpośrednich potomków ${ }^{23}$. W tej sytuacji spadkobierczyniami stały się córki Połubińskiego - Anna Marianna i Izabela. Ta pierwsza 9 X 1672 r. w wieku czternastu lat została wydana za mąż za Dominika Radziwiłła ${ }^{24}$. Po kilkuletnich sporach doszło do podziału dóbr, co skutkowało także podziałem archiwaliów tej rodziny ${ }^{25}$. Wspomniany Dominik Radziwiłł był protoplastą młodszej linii kleckiej tej rodziny, która w XIX w., wobec wymarcia pozostałych skupiła w swych rękach większość dóbr tego rodu ${ }^{26}$. W ten sposób dokumenty po kniaziach Trubeckich znalazły się w Archiwum Radziwiłłów w Nieświeżu, by ostatecznie, dzieląc jego późniejsze losy, znaleźć się w Archiwum Głównym Akt Dawnych ${ }^{27}$.

20 J. Wolff, dz. cyt., s. 381.

21 AGAD, AR, dz. X, sygn. 194, s. 56.

${ }^{22}$ J. Wolff, dz. cyt., s. 381.

23 J. Zawadzki, Papiery Potubińskich i ich dóbr, przechowywane w Archiwum Warszawskim Radziwittów, Miscellanea Historico-Archivistica, t. 9, 1998, s. 15.

24 A. Rachuba, Radziwitt Dominik, PSB, 1987, t. 30, s. 174.

25 J. Zawadzki, dz. cyt., s. 16.

26 T. Zielińska, Archiwa Radziwittów i ich twórcy, Archeion, t. 56, 1978, s. 112-113, taż, Archiwa różnych linii Radziwittów w polskich zbiorach publicznych, Miscellanea Historico-Archivistica, t. 7, 1997, s. 110.

27 Szerzej dzieje Archiwum Radziwiłłów z Nieświeża i zmiany w jego strukturze omawia w swych artykułach Rafał Jankowski - R. Jankowski, Burzliwe dzieje Archiwum 


\section{PODZIAE TYPOLOGICZNY MATERIAŁÓW ZWIAZZANYCH Z KNIAZIAMI TRUBECKIMI z ArChiWUM WarsZaWsKiego RadziWiŁŁów}

Można zauważyć, mając na uwadze cel jego zgromadzenia, że przechowywany w Archiwum Warszawskim Radziwiłłów zbiór materiałów archiwalnych jest związany z dziejami głównie jednej rodziny (kniaziowie Trubeccy) i jej spadkobiercy Krzysztofa Wołodkiewicza, oraz pojedynczego klucza dóbr, jakim była niewątpliwie włość trubecka. Można go więc pod pewnymi względami traktować jako archiwum majątkowe i spróbować usystematyzować zgodnie z przyjętymi dla tego typu archiwów zasadami.

Archiwa majątkowe, występujące też pod nazwą archiwów podworskich, spotkały się już ze słusznym zainteresowaniem badaczy, w tym także w kontekście sposobów ich porządkowania. W literaturze pojawiają się różne koncepcje podziału ich zasobów, np. Piotr Bańkowski proponował podział akt rodowych na cztery grupy rzeczowe: akta rodzinno-majątkowe, akta administracyjno-gospodarcze, akta związane z działalnością publiczną oraz varia ${ }^{28}$. Kazimierz Kaczmarczyk z kolei wydzielał aż siedem grup: akta rodzinne, akta majątkowe, akta gospodarczo-kasowe i rachunkowe, akta przedsiębiorstw, archiwa obce (rodzin obcych), akta obce i materiały do dziejów archiwów ${ }^{29}$. Obaj autorzy podkreślają jednak, że nie należy prezentowanych przez nich modeli stosować ściśle, ale modyfikować je w zależności od zaistniałych potrzeb.

Specyfika materiałów zgromadzonych w omawianym zbiorze powoduje, że najbardziej logiczne wydaje się przeprowadzenie ich podziału na 5 kategorii: akta prywatne (rodzinne), akta prawno-majątkowe, akta administracyjno-gospodarcze, akta związane z działalnością publiczną oraz varia. Analizując prezentowane archiwalia, można zauważyć, że przypisanie ich do którejś ka-

Radziwittów z Nieświeża od XVw. do 1838 r., Miscellanea Historico-Archivistica, t. 11, 2000, s. 35-68; tenże, Archiwum Radziwittów z Nieświeża od 1838 r. do XX w., Miscellanea Historico-Archivistica, t. 13, 2001, s. 131-168.

${ }_{28}$ P. Bańkowski, Porzadkowanie archiwaliów prywatnych, Archeion, t. 19-20, 1951, s. 210 .

29 Autor ten w odrębne kategorie wydzielał dodatkowo dokumenty pergaminowe, mapy, materiał sfragistyczny i fotograficzny - K. Kaczmarczyk, Archiwa rodzinne, ich literatura i porzadkowanie, Roczniki Historyczne, t. 23, 1957, s. 643-644. 
tegorii nie zawsze jest proste i jednoznaczne. Problemem było zakwalifikowanie np. materiałów związanych z wyjazdem Jerzego Trubeckiego do Moskwy. $\mathrm{Z}$ jednej strony są to niewątpliwie dokumenty prywatne i majątkowe, ale mając na uwadze, że wyjazd ten stanowił też problem polityczny i dotyczący szeroko pojętych ówczesnych stosunków międzypaństwowych, część dotyczących tego wydarzenia dokumentów można zakwalifikować do grupy spraw publicznych (np. list Stanisława Żabińskiego do Krzysztofa Wołodkowicza).

\section{a) akta prywatne}

Ważną częścią akt prywatnych w prezentowanym zbiorze są testamenty. Najstarszym z nich jest testament kniazia Jurija Nikiticza Trubeckiego spisany w lutym 1626 r. $^{30}$ Ponadto znajdują się tam też dwa testamenty Piotra Wiganta Trubeckiego (jeden z 5 II 1644 r., drugi z $4 \mathrm{~V}$ tego roku, będący de facto uzupełnieniem poprzedniego ${ }^{31}$ ) oraz akt ostatniej woli jego małżonki Halszki Druckiej-Sokolińskiej z 13 lutego 1653 r. Tekst tego ostatniego zachował się jedynie w formie wypisów z ksiąg sądowych grodzkich i ziemskich mińskich $^{32}$. Z testamentem Halszki związany jest dokument Jana Kazimierza z 5 IV 1653 r., w którym potwierdza on zapis Halszki o wyłącznym prawie opieki nad małoletnim Jerzym Trubeckim ${ }^{33}$.

Ważną, choć nieliczną kategorią akt jest też spuścizna epistolograficzna. Rozpoczyna ją niedatowany list wysłany przez Zofię z Rejów Drucką-Sokolińską do jej córki Halszki ${ }^{34}$. Dwa kolejne listy adresowane są do Piotra Wiganta. Nadawca pierwszego nie jest znany (najprawdopodobniej był to któryś z Sołtyków). Dnia 4 III 1644 r. zwracał się on do Trubeckiego w bliżej nieokreślonej sprawie, wspominając przy okazji o planach swego wyjazdu do województwa smoleńskiego i o otrzymaniu jakiejś nieokreślonej rzeczy. Osoba ta nie mogła jechać we wspomnianej sprawie i zalecała w zdecydowany sposób Trubeckiemu pośpiech („nie narzekaj WP na mię, gdy będziesz dzwonił w goły bęben”). Wspomina także o wyjeździe stryja Piotra do Wil$\mathrm{na}^{35}$. Nadawcą drugiego listu był Paweł Sołtyk, który 15 IV 1644 r. zgłaszał

\footnotetext{
30 AGAD, AR, dz. X, sygn. 173.

31 Tamże, sygn. 174.

32 Tamże, sygn. 192, s. 18-32.

33 Tamże, sygn. 195.

34 Tamże, sygn. 187, s. 2-4.

35 Tamże, s. 1.
} 
Trubeckiemu problemy z miejscowymi bojarami, którzy czynią szkody browarnikom i młynarzom, w związku z czym ponosił on straty i prosił o interwencję $e^{36}$.

$\mathrm{Za}$ dokument o charakterze prywatnym należy chyba uznać też list Aleksieja Trubeckiego do Jerzego Trubeckiego z 16 III 1656 r., w którym próbuje nakłonić go do przeniesienia się do Rosji ${ }^{37}$. Akurat ten dokument ze względu na wydźwięk, jak i okoliczności powstania można by było zakwalifikować również do kategorii akt publicznych, niemniej fakt, że list miał charakter korespondencji wewnątrz rodziny, jak i poruszał także sprawy dziedziczenia, pozwala na umieszczenie go w tej grupie.

Najpóźniejszy list w prezentowanym zbiorze pochodzi z 27 II 1668 r. Wołodkowicz zwracał się w nim do krajczego litewskiego Michała Kazimierza Radziwiłła z prośbą, aby ten wraz z Aleksandrem Hilarym Połubińskim pomogli mu w odzyskaniu spłaty reszty „sum trubeckich”38.

\section{b) akta prawno-majątkowe}

Akta tej grupy stanowią zdecydowaną większość wśród archiwaliów związanych z kniaziami Trubeckimi przechowywanych w Archiwum Warszawskim Radziwiłłów. Nie powinno to dziwić, jeżeli uwzględni się przyczynę, dla której materiały te zostały zebrane. Tu także można spróbować wydzielić kilka podgrup.

Pierwszą z nich będą dokumenty związane z zapisami majątkowymi. Zaliczyć można do niej: trzy zapisy Piotra Trubeckiego dla Halszki Druckiej-Sokolińskiej (zapis oprawy, drugi zastawny za długi i trzeci spisany przed śmiercią na całość dóbr) ${ }^{39}$, podobne zapisy Halszki dla Wołodkowicza, najpierw z 24 III 1647 r. na 30 tys. zł zapisanych na Trubecku, potem na dobra Holice z 10 X 1652 r. $^{40}$

Do tej podgrupy należy zaliczyć też kilka znajdujących się w zbiorze dokumentów dotyczących sprawy arendy Trubecka zawartej 30 IV 1643 r. Są to: umowa z Pawłem Sołtykiem, jej tłumaczenie na język polski, wypis z ksiąg grodzkich starodubowskich jeszcze jednego dokumentu dotyczącego tej aren-

\footnotetext{
36 Tamże, sygn. 177, s. 20-21.

37 Tamże, sygn. 196, s. 5-8.

38 Tamże, sygn. 194, s. 60-61.

39 Tamże, sygn. 175, s. 1-12.

40 Tamże, sygn. 192, s. 1-17.
} 
dy, również wystawionego 30 IV, różnego jednak od poprzednich. Rok później sporządzone zostały jeszcze: „aneks” do tej umowy z 17 II 1644 r. zmieniający niektóre postanowienia oraz potwierdzenie wystawione 30 III przez Piotra Wiganta i Halszkę Drucką-Sokolińską, że z powodu pilnej potrzeby poprosili o wcześniejszą wypłatę 12 tys. zł polskich należnych z tytułu arendy i udziału w daninach ${ }^{41}$.

Dobrze udokumentowane jest również przekazanie przez Jerzego Trubeckiego praw do jego majątków Krzysztofowi Wołodkowiczowi, uczynione przed jego wyjazdem do Moskwy. W omawianych archiwaliach znajdują się: oryginał jego zapisu z 6 III 1657 r., dwa wypisy powyższego dokumentu wzięte z ksiąg grodzkich nowogródzkich, dwa wypisy z tychże ksiąg z relacją Jerzego Trubeckiego o tym, że został zmuszony do wyjazdu i że wystawił zapisy Wołodkowiczowi także z 6 III 1657 r.; oryginał zapisu Jerzego na dobra Czarnorucz, Podrzecz i Sokolnię, które otrzymał on po swych dziadkach Janie Druckim-Sokolińskim i Zofii z Rejów wystawiony 11 III 1657 r. oraz potwierdzenie, że gdyby udało mu się wrócić, ureguluje Wołodkowiczowi wszystkie długi ${ }^{42}$. Z tą sprawą są związane jeszcze: oryginał potwierdzenia nadania tych dóbr wystawiony Wołodkowiczowi przez Jana Kazimierza 15 II 1658 r. wraz z wypisem z ksiąg grodzkich mińskich i list królewski do podskarbiego litewskiego Wincentego Korwina Gosiewskiego z informacją o tym nadaniu i poleceniem intromisji ${ }^{43}$. W omawianych archiwaliach zachowane są także dwie relacje z przekazania dóbr po Druckich-Sokolińskich Wołodkowiczowi: jedna sporządzona przez woźnych nowogródzkich Jarosza Sienczyłę i Adama Terajewicza z 6 III 1657 r., zachowana w formie wypisu z ksiąg ziemskich nowogródzkich z 1661 r., oraz oryginał listu urzędnika skarbowego Macieja Pajkowskiego z 4 VIII $1660 \mathrm{r}^{44}$

Drugą podgrupą w aktach prawno-majątkowych są kwity związane z zaciąganymi pożyczkami. W omawianym zbiorze znajduje się 18 takich dokumentów. Wystawcą aż 15 z nich był Piotr Wigant Trubecki, czasem występujący razem z żoną Halszką Drucką-Sokolińską ${ }^{45}$. Dwa kolejne zostały

41 Tamże, sygn. 177 , s. 2-19.

42 Tamże, sygn. 196, s. 1-49.

43 Tamże, s. 50-57.

44 Tamże, s. 58-68.

45 Tamże, sygn. 179, s. 3-4; sygn. 180 , s. 1-8; sygn. 181, s. 1-4; sygn. 182, s. 1-8; sygn. 185 , s. $10-13$; sygn. 186; sygn. 188 , s. 1-2, 5-6, 10-13. 
wystawione przez Pawła Sołtyka: jeden z 1643 r. na pożyczenie 500 zł od arendarzy trubeckich Arona Mojżeszowicza i Mordasza Kałmanowicza ${ }^{46}$ oraz drugi, niedatowany, na 1000 zł wzięte od Adama z Byszowca Kryckiego ${ }^{47}$. Odnotowany został także jeden dokument tego typu Stefana Markowskiego na pożyczkę 50 zł wziętą od Krzysztofa Wołodkowicza pod zastaw starego kwitu dłużnego Pawła Sołtyka ${ }^{48}$.

Dużą część archiwaliów związanych z kniaziami Trubeckimi przechowywanych w Archiwum Warszawskim Radziwiłłów stanowią materiały procesowe wynikające $\mathrm{z}$ licznych spraw sądowych, jakie prowadził Piotr Wigant Trubecki. Jest to trzecia podgrupa, jaką można wydzielić w obrębie akt prawno-majątkowych. Spora część sporów sądowych ciągnęła się jeszcze po śmierci Piotra Wiganta i stroną pozywaną była wdowa po nim Halszka Drucka-Sokolińska. W omawianych archiwaliach można znaleźć akta procesowe dotyczące wyroków wydanych w związku z niespłacaniem branych pożyczek. Takie procesy Trubeccy mieli ze Stefanem Markowskim ${ }^{49}$, Janem Druckim-Sokolińskim ${ }^{50}$, Aleksandrem Minwidem ${ }^{51}$, Samuelem Kułakiem ${ }^{52}$, Andrzejem Przezrowskim ${ }^{33}$ i Pawłem Sołtykiem ${ }^{54}$. Piotr Wigant prowadził także sprawy o charakterze karnym. Najpoważniejsze zarzuty ciążyły na nim w procesie z Samuelem Porażyckim, który został przez niego uprowadzony i przez wiele miesięcy bezprawnie więziony ${ }^{55}$. Inne odnotowane procesy dotyczyły prowadzonych na przełomie lat trzydziestych i czterdziestych XVII w. sporów o granice włości trubeckiej z Iwanem Sołtykiem ${ }^{56}$, Adamem Kryckim ${ }^{57}$, Janem Piorem, Samuelem Niemirowskim i Bartłomiejem Żukiem ${ }^{58}$. Warto zaznaczyć, że większość materiałów nie jest kompletna: czasem są to pojedyn-

46 Tamże, sygn. 188, s. 3-4.

47 Tamże, sygn. 193, s. 23.

48 Tamże, s. 31-32.

49 Tamże, sygn. 180.

50 Tamże, sygn. 182, s. 9-18; sygn. 193, s. 15-19.

51 Tamże, sygn. 181, s. 5-8.

52 Tamże, sygn. 185, s. 14-17; sygn. 193, s. 12-14.

53 Tamże, sygn. 185, s. 8-9.

54 Tamże, sygn. 188, s. 14-25.

55 Tamże, sygn. 183. Obie strony po zakończeniu tego konfliktu toczyły jeszcze jeden spór o nieoddane pieniądze - tamże, sygn. 184.

56 Tamże, sygn. 176, s. 3-9.

57 Tamże, sygn. 179, s. 7-8.

58 Wszystkie omawiane sprawy znajdują się w sygn. 178. 
cze pozwy lub same dekrety sądowe. Wyjątkowo bogato udokumentowane są jedynie procesy ze Stefanem Markowskim i Samuelem Porażyckim.

Odrębnego potraktowania wymagają materiały z dwóch procesów sądowych, gdyż nie brał w nich już udziału Piotr Wigant Trubecki. Pierwszy z nich dotyczył odszkodowania za bezprawne przekazanie Trubecka Moskwie, a wytoczyli go Jan Drucki-Sokoliński wraz z Halszką królewskim komisarzom Mikołajowi Abramowiczowi i Samuelowi Osińskiemu, zakończony zawarciem ugody ${ }^{59}$. Drugi proces dotyczył podziału „sum trubeckich” w związku z roszczeniami Bazylego Sołtyka ${ }^{60}$.

Część nieuregulowanych długów po śmierci Piotra Wiganta i Pawła Sołtyka spłacił ostatecznie Krzysztof Wołodkowicz. Niektóre z nich są powiązane z materiałami procesowymi, ale w omawianym zbiorze znajduje się też kilka listów kwitacyjnych nienależących do nich i stanowiących samoistną całość. Jako przykłady można tu podać m.in. dokumenty z potwierdzeniem spłaty wystawiane przez Bohdana Kraskowskiego, Iwana Sołtyka i jego żonę Zuzannę z Roguskich, Annę Przewalską Nikityczową Żdanowiczową czy mieszczanina szkłowskiego Stefana Szłyka ${ }^{61}$.

Przy omawianiu dokumentów o charakterze prawno-majątkowym warta odnotowania jest, oblatowana w księgach grodzkich nowogródzkich, relacja Wołodkowicza o zaginięciu szkatuły z dokumentami, co - jak wyraźnie zostało zaznaczone - miało związek z obawami o późniejsze bezprawne wykorzystanie przechowywanych tam dokumentów ${ }^{62}$.

\section{c) akta administracyjno-gospodarcze}

Wśród prezentowanych $\mathrm{w}$ niniejszej pracy archiwaliów można znaleźć także źródła gospodarcze związane z zarządzaniem dobrami, choć nie jest ich dużo. Pojawiają się one niemal wyłącznie w związku z zapisami własnościowymi. Będą to: inwentarz majętności Trubeck (faktycznie jej części) sporządzony 4 IV 1644 r. przy przekazywaniu go Halszce Druckiej-Sokolińskiej ${ }^{63}$, podobny inwentarz sporządzony przy przekazywaniu w arendę części włości (Horodca) sędziemu ziemskiemu mińskiemu Krzysztofowi Ciechanowieckie-

\footnotetext{
59 Tamże, sygn. 194, s. 1-10.

60 Tamże, s. 13-24, 31-50.

61 Wszystkie potwierdzenia tego typu znajdują się w sygn. 193.

62 Tamże, sygn. 197, s. 8-11.

63 Tamże, sygn. 175, s. 13-16.
} 
mu z 1644 r. $^{64}$ oraz inwentarz wsi Żukowo zastawionej Samuelowi Kułakowi i jego żonie Zofii Pieslakównie z 1641 r. ${ }^{65}$ Do tej grupy akt należy też zaliczyć inwentarz z 1642 r. z wykazem nieodebranego jeszcze dziakła i dani miodowej sporządzony przez Jana Boliszańskiego ${ }^{66}$. Jako ostatni z tej grupy należy wskazać niedatowany krótki rejestr zawierający liczbę włók z dóbr Podrzecz, Czarnorucz, Sokolec sporządzony najprawdopodobniej podczas intromisji Krzysztofa Wołodkowicza w te dobra w marcu 1657 r. ${ }^{67}$

W odrębną podgrupę można wydzielić rachunki związane z wypłatą „,sum trubeckich", których w omawianych archiwaliach znajduje się kilka. Zostały one sporządzone w latach sześćdziesiątych XVII w., jedynie ostatni z nich spisano w $1670 \mathrm{r} \cdot{ }^{68} \mathrm{~W}$ tej kategorii można jeszcze umieścić rejestr z wzajemnej „likwidacji” roszczeń przeprowadzony w kwietniu 1659 r. między Wołodkowiczem a Bazylim Sołtykiem ${ }^{69}$.

\section{d) akta związane z działalnością publiczną}

Akta dotyczące spraw publicznych są w omawianych archiwaliach bardzo skromnie reprezentowane. $Z$ trzech przedstawicieli rodu, których dotyczą zachowane materiały, dwóch - Jurij Nikitycz i jego wnuk Jerzy Trubecki nie pełniło żadnych urzędów. W wypadku tego ostatniego przyczyną był niewątpliwie brak jego pełnoletności. Jedynie Piotr Wigant był najpierw podczaszym starodubowskim, by potem dość szybko awansować na urząd podkomorzego starodubowskiego. Niemniej i w jego wypadku nie zachowały się żadne dokumenty dotyczące działalności publicznej.

Do grupy akt związanych ze sprawami publicznymi zaliczyć można jedynie trzy listy związane z kulisami przygotowań do wyjazdu Jerzego Trubeckiego do Rosji. Wszystkie one są adresowane do Wołodkowicza. Pierwszy Stanisława Żabińskiego z 14 stycznia 1656 r., w którym pyta, dlaczego Jerzy Trubecki nie został jeszcze odesłany i informuje o groźbach Aleksieja Trubeckiego $^{70}$. Drugi to list szlachty sejmiku wołkowyskiego potwierdzający, że odesłanie Trubeckiego nastąpi wbrew jego woli po ostrzeżeniu o wtargnię-

\footnotetext{
64 Tamże, sygn. 177, s. 24-27.

65 Tamże, sygn. 179, s. 5-6.

66 Tamże, sygn. 176, s. 10-22.

67 Tamże, sygn. 196, s. 69.

68 Tamże, sygn. 194, s. 51-59.

69 Tamże, s. 25-30.

70 Tamże, sygn. 196, s. 1-2.
} 
ciu na tereny powiatu liczącego trzystu jeźdźców oddziału moskiewskiego i naciskach w tej sprawie ${ }^{71}$. Trzeci dokument to list Piotra Galińskiego z $4 \mathrm{~V}$ 1656 r., w którym informuje o wynikach negocjacji z wysłannikami carskimi i żądaniach cara ${ }^{72}$.

\section{e) varia}

W tej kategorii, zgodnie z zaleceniami P. Bańkowskiego, umieszczane są z reguły materiały przybliżające dzieje archiwum, w tym jego sumariusze oraz archiwalia o nieokreślonej treści lub o nieznanej proweniencji ${ }^{73}$. Takie dokumenty można znaleźć i w omawianym zbiorze.

Źródłem do dziejów archiwum jest wspominany już sumariusz dokumentów związanych ze sprawą trubecką, sporządzony 1 III 1659 r. przez Krzysztofa Wołodkowicza ${ }^{74}$. Dokumentem o nieokreślonej bliżej proweniencji jest natomiast pusta, niedatowana membrana z podpisem Piotra Trubeckiego ${ }^{75}$. Naniesiona na nią została zapiska informująca, że oblig ten został odebrany od Robczyckiego i oddany Janowi Druckiemu-Sokolińskiemu na potrzeby bliżej nieokreślonego procesu. Jak można przypuszczać, autorem zapiski był któryś z synów Druckiego-Sokolińskiego, skoro pisze on o przekazaniu do rąk „marszałka orszańskiego Pana ojca i dobrodzieja mego"76.

Przechowywane w Archiwum Warszawskim Radziwiłłów materiały związane z kniaziami Trubeckimi można podzielić na dwie odrębne grupy. Jedna z nich to materiały związane z działalnością trzech przedstawicieli rodu Trubeckich, którzy w XVII stuleciu osiedli na obszarze Rzeczypospolitej: Jurija Nikiticza Trubeckiego, jego syna Piotra Wiganta oraz wnuka Jerzego Trubeckiego. Największą ich część stanowią archiwalia związane z Piotrem Wigantem, co ma związek także z licznymi prowadzonymi przez niego procesami, głównie o spłatę zaciąganych przez niego pożyczek. Druga grupa to archiwalia związane z problemem spłaty tzw. sum trubeckich, czyli rekompensaty za oddany Moskwie w 1645 r. Trubeck. Dokumenty związane z tą sprawą

71 Tamże, s. 3-4.

72 Tamże, s. 9.

73 P. Bańkowski, dz. cyt., s. 210.

74 AGAD, AR, dz. X, sygn. 197, s. 1-7.

75 Tamże, sygn. 185, s. 18-19.

76 Jan Drucki-Sokoliński miał trzech synów: Jerzego, Stanisława i Hieronima Olbrachta - M. Nagielski, Sokolinski (Drucki Sokolinski) Jan, kniaź (zm. 1651 r.?), PSB, 2000-2001, t. 40, s. 38. 
były uzupełniane także w późniejszym okresie. Jego powstanie należy wiązać z osobą wojewody mińskiego Krzysztofa Wołodkowicza.

Omawiane materiały archiwalne znalazły się w Archiwum Radziwiłłów drogą koligacji rodzinnych. Bezpośrednim spadkobiercą Trubeckich był Krzysztof Wołodkowicz, ożeniony z wdową po Piotrze Wigancie Trubeckim, Halszką z Druckich-Sokolińskich. Po nim dokumenty te przeszły drogą dziedziczenia do Połubińskich, a następnie do Radziwiłłów, dzieląc późniejsze losy ich archiwum rodzinnego.

Bibliografia

Bańkowski P., Porzadkowanie archiwaliów prywatnych, „Archeion”, t. 19-20, 1951, s. $194-$ $-216$.

Jankowski R., Archiwum Radziwittów z Nieświeża od 1838 r. do XX w., „Miscellanea Historico-Archivistica", t. 13, 2001, s. 131-168.

Jankowski R., Burzliwe dzieje Archiwum Radziwittów z Nieświeża od XV w. do 1838 r., „Miscellanea Historico-Archivistica”, t. 11, 2000, s. 35-68.

Kaczmarczyk T., Archiwa rodzinne, ich literatura i porzadkowanie, „Roczniki Historyczne", t. 23, 1957, s. 633-646.

Nagielski M., Sokolinski (Drucki Sokoliński) Jan, kniaź (zm. 1651 r.?), PSB, t. 40, s. 37-38.

Pietkiewicz K., Wielkie Księstwo Litewskie pod rządami Aleksandra Jagiellończyka, Poznań 1995.

Rachuba A., Radziwitt Dominik, [w:] PSB, 1987, t. 30, s. 173-176.

Wolff J., Kniaziowie litewsko-ruscy od końca czternastego wieku, Warszawa 1895.

Zawadzki J., Papiery Potubińskich i ich dóbr, przechowywane w Archiwum Warszawskim Radziwittów, „Miscellanea Historico-Archivistica”, t. 9, 1998, s. s. 13-32.

Zielińska T., Archiwa Radziwittów i ich twórcy, „Archeion”, t. 56, 1978, s. 105-129.

Zielińska T., Archiwa różnych linii Radziwittów w polskich zbiorach publicznych, „Miscellanea Historico-Archivistica”, t. 7, 1997, s. 107-113.

Долгоруков П., Российская родословная книга, ч. 1, Санкт Петербургъ 1854

Численность Населения Российской Федерации по муниципальным образованиям на 1 января 2015 года, Москва 2015, (publikacja dostępna w wersji elektronicznej: http://www.gks.ru/free_doc/doc_2015/bul_dr/mun_obr2015.rar [dostęp z dnia 11 XI 2015 r.]) 


\section{Summary}

Archival materials concerning princes Trubecki in the fonds Warsaw Archives of the Radziwiłł Family - origins and typology

The presented article is aimed at introducing materials concerning the history of the Trubecki family stored in the fonds Warsaw Archives of the Radziwiłł Family. Those materials can be divided into two groups. The first group consists of information on three successive representatives of the family who settled on the territory of the Republic in the 17th century (Jurij Nikiticz, Piotr Wigant and Jerzy Trubecki); this part is a result of their documenting activity. The second group of materials on the history of this family stored in the Central Archives of Historical Records has been collected on account of the problem of paying "the Trubeck sums" (Polish "sumy trubeckie") - compensation for making over Trubeck to Moscow by the Republic. Attempts to settling it were made by Piotr Wigant Trubecki's widow, Halszka Drucka-Sokolińska with her second husband Krzysztof Wołodkowicz, and after her death - by Wołodkowicz himself, who became a heir of the adjudged sum as a result of a trip of Jerzy Trubecki's stepson to Moscow in 1657.

The article is an attempt to establish a route the documents used to get to the Central Archives of Historical Records. Thanks to that a hypothesis was drawn, that a creator of the mentioned documents collection was a voivode of Mińsk Krzysztof Wołodkowicz, and their transmission to the Radzwiłł Family's Archives was made due to family connections. A heir of Wołodkowicz was Aleksander Hilary Połubiński, and then these documents, with his daughter Anna Marianna's hand in marriage, became a property of the Radziwiłł Family's younger line from Kleck. Also an attempt of systematization of the archival materials was made, and these were divided into private documents, legal and possessions documents, administrative and economic documents, public activity documents and varia. 